\title{
一般演題
}

看護・栄養 $(\mathbf{V I})$

座長池井みや子

睪丸腫瘍治療後発症した放射線腎炎と思われる腎不全例の看護·

国立病院医療センタ一血液透析室鈴木ちひさ，武智喜代子，田中千恵子 佐藤美稚子, 渡辺 政信, 斉間 恵樹 中村 雄二, 岩動孝一郎

困難な維持透析についての 1 症例報告

東京女子医科大学腎臓病総合医療センター透析室 見並 雅美, 大橋 信子, 犬塚 信子 鈴木 利明, 佐中 孜, 太田 和夫

管理困難患者の看護 一「生活目標」「自主管理透析」を 1 手段として

松下電器健保松下病院腎不全センター＼cjkstart原本 広子, 瀬口 恵子, 佐藤登代子 霜尾 満代

透析導入患者への医療者の関わり 一透析の受容に困難をきたしたケースを看護して

北里大学 斉藤 公子, 野地 金子, 高橋 和加 加藤 順子

討 


\section{睪丸腫瘍治療後発症した放射線腎炎と思われる腎不全例 の看護}

鈴木ちひさ 武智喜代子 田中千恵子 佐藤美稚子 渡辺 政信 斉間 恵樹 中村 雄二 岩動孝一郎 国立病院医療センター血液透析室

〔はじめに〕睪丸セミノーマの為, 術後放射線療法施 行し放射線によると思われる腎炎発症。癌の宣告の上に 腎不全及び高血圧の不安と闘いつつ社会復帰を目指す患 者を看護する機会を得たので報告する。

〔症例〕 Y.N., 48 歳, 男性, 中学教師。既往歴: 左停 留睪丸。現病歴: S 51 年 12 月下腹部鈍痛出現. S 52 年 7 月某病院にて左睪丸セミノ一マ診断, 除睪術施行, 左 右後腹膜転移巣認めた為， ${ }^{60} \mathrm{Co}$ を左腎部に $38 \mathrm{~Gy}$ ，右腎 部に $36 \mathrm{~Gy}$ 照射. S 53年 3 月慢性腎不全で某ガンセン ター入院. 放射線腎炎の疑いで PD 施行するも, 嘔気, 頭痛持続する為頭部 CT スキャンで脳転移を認め, ${ }^{60} \mathrm{C}_{0}$ 照射し治癒する. S 56年 10 月, BUN $77 \mathrm{mg} / \mathrm{d} l, \mathrm{Cr} 7.1 \mathrm{mg} /$ $\mathrm{d} l, \mathrm{~K} 4.5 \mathrm{mEq} / l, \mathrm{Hb} 8.8 \mathrm{~g} / \mathrm{d} l, \mathrm{BP} 190 / 100 \mathrm{mHg}$ と腎不全 の悪化を認め $\mathrm{HD}$ 導入目的にて入院. 同年 11 月活性炭 服用開始するも無効の為, S 57年 1 月 26 日, HD 導入. 以後 2 回/週透析を施行している.

〔看護の展開〕 $\mathrm{HD}$ が良好に経過するならば，癌を克 服し，完全に社会復帰出来るものと思っていたが，医師 が患者の高血圧は腎生検未施行なので確定ではないが放 射線腎炎由来ならば悪性像を示し易いので無理のない生 活をと説明すると, 嘔吐, 食欲不振が始まり食事管理が 不十分な状態になった。医師と相談し, 胃透視, 頭部 CT スキャン, ガリウムシンチ, 眼底検査, 血清浸透圧測定 等で器質的変化無い事を確認し, 嘔吐は復職問題も加味 された不安の現れと判断し, 食事制限の当面の解除, 外 出泊を勧め, 食欲回復と気分転換を図り, 頻回の面接及 び妻への食事指導を行ない嘔吐消失, 食欲回復を見, 社 会復㷌に向け転院となった。今後高血圧の管理も含め, 長期の経過観察が必要なので援助を続けるつもりであ る.

\section{困難な維持透析についての 1 症例報告}

見並 雅美 大橋 信子 犬塚 信子 鈴木 利昭 佐中 孜 太田 和夫 江良 和雄

東京女子医科大学腎藏病総合医療センター透析室 近年, 血液浄化法の進歩により, 腎不全患者の予後は 大幅に改善されてきている。

本症例は, 60 歳男性, 職業は産婦人科医で, 糖尿病性 腎症により透析導入以来 10 年目を迎えるが,ここ半年ほ ぞ透析中の血圧変動が激しく, 適正な維持透析が困難に なってきたため，その経過と看護側のアプローチについ
て報告する。対策としてアルブミン，プライミング，重 曹透析，血液濾過などを施行するが，おのおの問題点が 生じ元のアセテート透析に戻る。その際, 体外循環血液 量を減少させる工夫をした。また透析中血液流量, 除水 速度・血圧・脈拍・自覚症状・昇圧剤などについて細か い観察・記録をとりそれを評価し，個々にあった透析方 法を見い出す努力をした。同時に水分制限の必要性を再 教育し, 体重増加が基準体重の 4 〜 5 \%増で抑えられる ようになると透析中の血圧が落ち着いてきた。本症例を 通して, 血液浄化法が進歩, 多様化しても, 自己管理が 不十分であれば適正な維持透析は望めないことが認識さ れた。また導入時の指導とは異なり 10 年の維持透析を経 験し，しかも職業が医師である患者に再度自己管理につ いて指導することのむずかしさを痛感した。そして糖尿 病・加齢現象・長期透析によって強い動脈硬化を来たし ている患者が安定した透析を受けられるよう援助するこ と，その患者について十分な観察・記録をとり，それを 評価しながら患者の個々にあった透析方法を改めて探っ てみることの重要性について認識した。

\section{管理困難患者の看護 一「生活目標」「自主管理透析」を 1 手段として}

原本広子瀬口 恵子 佐藤登代子 霜尾 満代

松下電器健保松下病院腎不全センター

透析者が自立し, 社会復帰を達成し, 積極的な透析生 活を送る為のあらゆる側面からの援助活動が私達の使命 である。管理能力を持ちながら，精神的ストレスと，意 志薄弱の為に管理困難に陥った 2 症例に, 「生活目標の明 確化」と「教育目的での自主管理透析」を試み，管理実 践の方向づけを見出したので紹介する.

〔症例 1 〕 32 歳, 女性, 透析歷 2 年 6 力月, ネフロー ゼ，主婦で勝ち気，導入時腹水著明，消化管出血，肺炎 を合併, 聴力障害と歩行困難あり。長期入院, 聴力障害 による疎外感, 離婚話, 子供や経済面での不安などの精 神的ストレスから，管理不良が目立ったが，妻，母親の 役割意識の強いことに着眼。家庭生活を目標に，1）通 院透析への移行, (1) 積極的な機能訓練, (2) 家族の協力態 勢，(3) 危険防止対策，2)生活管理指導の徹底，(1) 食事 管理の向上, (2) 精神面の安定化, (3) 体調管理の自覚, 3 ) 社会復帰への援助, (1) 家庭生活の充実, (2) 生きがいの達 成を具体的に指導した。結果, 通院透析への移行, 体調 管理の充実が実現できた。

〔症例 2 〕 23 歳, 女性, 無職, 透析歴 3 年 10 力月, 慢 性腎炎。管理不良で入院が頻回．消化管出血，肺炎を合 併し聴力障害あり。内向的でわがまま, 集団生活体験が 少い。透析拒否などから，「自立」「社会参加ができるよ 
うに」を目標に，1）自立ができる為の援助，(1)教育的 自主管理透析の実践，(2)労働への意欲をもたせる，(3)自 律訓練，(4)家族の協力，2）社会参加への働きかけ，(1) 院外教育での集団生活参加（透析旅行，八イキング，料 理講習会など)，(2)夜間高校進学を指導した。結果，積極 的態度と自活への方向づけができた。

〔まとめ〕 1) 管理不良の原因追求，2）指導目標の 明確化，3）十分な情報交換，4）家族の協力，5）継 続看護を, 種々の管理困難者に今後も積極的にとりくみ たい。

\section{透析導入患者への医療者の関わり 一透析の受容に困難 をきたしたケースを看護してー}

斉藤 公子 野地 金子 高橋 和加 加藤 順子 北里大学

慢性腎不全患者は, 透析導入によって, 器械や医療者 に依存して生きる人生を強いられる。その為, 導入前後 の患者の葛藤は深刻である。この時期に医療者がどのよ うに関わるかによって，その患者の透析人生やその後の 医療者との関係が大きく左右されると言っても過言では ない.

今回，私達は，導入期に透析の受容に困難をきたした

\section{討 論}

池井 見並さんの演題に質問させていただきたいんで すけれども，糖尿病といいますと，よく発表の出るとこ ろでは，身体面的なところが非常に多いわけですね。そ の身体面が非常に出る部分におきまして, 精神的な面で 患者さんのストレスというのがあると思いますけれど も，その精神的な面での援助のポイントは何なんでしょ うか.

鈴木 まず糖尿病の方，この例は特殊でないかと思い ますが，どうしてかと申しますと，透析に入りましてか ら 10 年以上経過しているということが一つあります.こ の例以外の例をとってみましたら，まず，いつも私ども の方で困るのは，まず透析に入ってきている方は目が見

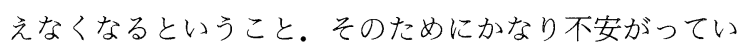
るということです。それからそういうふうな状態で透析 に導入されますから，特にDMの方でも，若い人の場合 はこれから先どうしていくかという生活設計とか，それ が全く見当がつかなくなりまして, 全く自分の将来が不 安になるというのが一番大きいと思います。この症例の 場合は，まず一つはドクターであるということ，それか ら透析年齢が 10 年以上たっているということで,かなり
2 症例（(1) M. O. 46 歳男性(2) N. I. 52 歳女性）の看護を 振り返り, 透析受容困難な患者への医療者の関わりを考 察した。尚, 私達は, 透析導入期の受容目標を次の点に おいた。(1) 透析の必要性が解り, 安心して透析が受けら れる. (2) 透析生活の仕方がわかり，社会生活への自信が できる，以上のケース 2 例を通して，次の事項が確認で きたので報告したい.

1) 自覚症状がなく導入する場合は，とくに患者が人 間像や生活面への配慮を忘れず，患者が透析の必要性や 不均衡症候群について理解できるよう深く関わることが 大切である。

2 ）透析拒否をしている場合は，まず，その理由が何 なのかを見極め対応する.また, 透析の受けとめが出来 ていない時期は, 自己管理の指導をす寸めても聴く耳が ないので，患者の反応を確かめながら指導を開始してい く事が大切である。

3 ) 緊急透析導入の場合は, 重病感が強くかつ社会復 帰が遅れがちであるので, 医療者は充分関わって教育を 徹底することが大切である。

4) 最低量の透析で頑張る場合は, 生活範囲が狭まっ ていないかを把握し, 充分な自己管理と透析の正しい理 解ができるよう関わることが大切である.

そういう面では不安としてはないと思います。逆に，不 安というよりも諦念感といいますか, あきらめ的な印象 を持っていまして，ある面ではドクターですから，そう いうふうな, 糖尿病の方は予後が悪いということを何度 も認識しています．普通の方の場合とちょつと違うと思 いますが。

楮山(東京女子医科大学) 一つは, O氏が疑問を持つ て，医療者のかかわりの中で信頼関係があるナースでは 作れなかった。それで受持患者を替えて，そこで信頼を 作り得たと.そこで患者が変化していったということで， O氏の場合にかかわり方を発表されていたんですけれど も, その信頼をなぜ変化させ得たかという, そこら辺, 前のナースと受持ナースを替えたことの，そこのかかわ り方がどういうふうに違っていたかということを，ぞの ように分析したでしょうか.

斉藤 初めに受け持っていたナースが，透析室勤務に なりましてから半年ぐらいの時期だったんです。一応指 導しなければいけないというところをとても認識強くし ていた時期だったものですから，一生懸命その患者さん の話に耳を傾けようとはしていたにもかかわらず，やっ 
ぱり対応しきれなかったんですね。結局は，水を飲み過 ぎているから，あなたは今飲むことがあなたの体の管理 ができなくなっている理由なんだから，やめた方がいい ですよということを一つ㧍話しするにしても，その指導 の方が前面に出てしまっていたところがあるんです。な ぜなのか分からないということでリーダーナースの方に 相談があったものですから, 受け持ちを変えてみて, 話 を聞いてみたところ，そこの話の聞き方が一番違ってい
たのかもしれないと私たちは考えたんです．とにかく透 析をしないでもう少し生きていける方法はないのかと， あと 10 年間は生きたいんだけれども, どうにかそういう 方法はないのかというところを強く訴えていたわけです 亦。そこをキャッチしないで，指導だけが先行していた 以前のナースとの違いが少し見えてきたと。そこだった ようなんです。 